\title{
Characteristics and Antagonistic Potential of Pseudomonas spp. against Pratylenchus loosi
}

\author{
Rahanandeh $\mathrm{H}^{1 *}$, Khodakaramian $\mathrm{G}^{2}$, Hassanzadeh $\mathrm{N}^{1}$, Seraji $\mathrm{A}^{3}$ and Asghari $\mathrm{SM}^{4}$ \\ ${ }^{1}$ Department of Plant Pathology, Science and Research Branch, Islamic Azad University, Hesark Ponak, Tehran, Iran \\ ${ }^{2}$ Department of Plant Protection, College of Agriculture, Bu - Ali Sina University, Hamadan, Iran \\ ${ }^{3}$ Department of Plant Protection, Iranian Tea Research Institute, Lahijan, Guilan, Iran \\ ${ }^{4}$ Department of Biology, Faculty of Basic Sciences, University of Guilan, Rasht, Iran
}

\begin{abstract}
The tea root lesion nematode, Pratylenchus loosi, has been shown internationally serious nematode pest causing yield losses in tea plantations. The purpose of this study is that, with regard to biological control as one of the main section nematodes and sustainable agriculture, integrated management systems, allowing application and Pseudomonas fluorescens in the rhizosphere of tea root lesion nematode control to check. To evaluate these potentiality more than forty bacterial strains were collected from rhizosphere of tea plants and screened for their antagonistic activities towards adult and juvenile Pratylenchus loosi for population density reduction under in vitro condition. Eight selected isolates with nematicidal activity were characterized and identified. All belonged to the genus Pseudomonas. Seven strains were identified as Pseudomonas fluorescens and one as $P$. aeruginosa. Death percentage of juveniles ranged from $63.10 \%$ to $95.24 \%$ for $P$. fluorescens (Rh-36) and P. fluorescens (Rh-19), respectively.
\end{abstract}

Keywords: Camellia sinensis; RLNs; Pratylenchus loosi; Bacterial biocontrol agents

\section{Introduction}

Tea, Camellia sinensis (L).O. Kuntze, cultivated on 2.85 million ha, with a total production of 3.87 million ton per annum. Tea is considered as a strategic economic crop in Iran. According to FAO statistics in 2010, tea is already harvested in Iran from a surface of about 32000 ha [1]. This plant is attacked by more than 30 animal species. Amongst the various constrains to tea production, plant parasitic nematodes have a significant economic importance [2]. As a permanent crop grown as a monoculture, tea creates a stable micro-climate and provides a uniform food environment for several pests and diseases. More than 40 species of plant parasitic nematodes, belonging to 20 genera, have been reported from tea worldwide [3]. Two species of root-lesion nematodes (RLNs), Pratylenchus loosi Loof 1960 and P. brachyurus (Godfrey) Godey, are known to attack tea plants in some producing countries such as Sri Lanka, Philippines, Japan, China, Bangladesh, Taiwan, India, Vietnam, USA and Australia [4]. Among these species, P. loosi, was seen for the first time in 1930 by Gadd in tea gardens in Sri Lanka and in 1960 was reported by Loof [5]. This nematode caused a severe damage on tea plants and remarkably reduced crop yields in many other countries such as India, China, Japan and Bangladesh [3]. Pratylenchus loosi is a serious parasite of tea in Iran [6,7], causing losses in tea quantity and quality [8].

The side, undesired effects of common pesticidesled the investigators to develop and apply environmentally safe pest management strategies, including microbial-based compounds. Bacteria, yeast and filamentous fungi are general inmates of soil and plant surfaces, and some species are known for various mechanisms limiting disease incidence or severity [9-17].

Various management systems have been designed to envisage and introduce more efficient compounds against plant-parasitic nematodes, notably in the past thirty years [18-20]. The rhizoplane and rhizosphere are colonized and differently affected by many microorganisms. Plant growth promoting bacteria supply plant growth promoting matter and antibiotics. They prepare fundamental guarding against nematode diseases [21]. Up to $10 \%$ of rhizobacterial populations have been shown to be antagonist on parasitic nematodes. However the application of crop rotations and mulches as a procedure to increase levels of rhizoflora antagonists to plant-parasitic nematodes showed variable results [22-25].

The nematicidal activities of these bacteria may be attributed to antibiotics produced in the agar medium. The seed or tuber treatments with non-parasitic rhizobacteria and even their application in soils may affect root penetration by nematodes on diverse crops, both in greenhouse and field conditions. Use of these non-parasitic rhizobacteria among other beneficial microorganisms such as root-nodule bacteria, arbuscular mycorrhizae, saprophytic and opportunistic fungi appeared advantageous for suppression of nematode populations on various crops [26-31].

Aim of this study was to isolate and characterize some native bacterial strains capable to suppress tea root-lesion nematodes, under laboratory condition.

\section{Materials and Methods}

\section{Sampling and nematode extraction}

Sampling for extraction of $P$. loos $i$ was performed in the years 20102011 , in infested tea plantation of north Iran. In each year 20 complex

*Corresponding author: H. Rahanandeh, Department of Plant Pathology, Science and Research Branch, Islamic Azad University, P. O. Box 14155/4933, Hesark Ponak, Tehran, Iran, E-mail: Rahanandeh20@yahoo.com

Received July 23, 2012; Accepted October 15, 2012; Published October 20 , 2012

Citation: Rahanandeh H, Khodakaramian G, Hassanzadeh N, Seraji A, Asghari SM (2012) Characteristics and Antagonistic Potential of Pseudomonas spp. against Pratylenchus loosi. J Plant Pathol Microb 3:140. doi:10.4172/2157-7471.1000140

Copyright: $(2012$ Rahanandeh $\mathrm{H}$, et al. This is an open-access article distributed under the terms of the Creative Commons Attribution License, which permits unrestricted use, distribution, and reproduction in any medium, provided the original author and source are credited. 
sample were collected at infested tea gardens. Each sample consisted of dozens of tiny sub samples collected at $15-25 \mathrm{~cm}$ depth and $20 \mathrm{~cm}$ distance from the crown. The samples, one and a half pounds of tea and ten gram tea roots, were later transferred to the laboratory. The tea root lesion nematode separation method was used [32], and centrifugal separation was performed according to the method of [33], from collected roots.

\section{Isolation of antagonistic bacterial strains}

A total of 40 bacterial strains were isolated from the rhizosphere of tea plants from the Guilan province (North of Iran). All isolates were cultured on both nutrient agar and King's B media. In brief, one gram of soil was suspended in $100 \mathrm{ml}$ sterilized distilled $\mathrm{H}_{2} \mathrm{O}$ containing one gram of gelatin and then shacked for 30 minutes at $70 \mathrm{rpm}$. The resultant suspensions were diluted up to $1 \times 10^{7}$ and streaked on agar media and kept at $27 \pm 1^{\circ} \mathrm{C}$ for $72 \mathrm{~h}$. Bacterial colonies were purified and stored at $4^{\circ} \mathrm{C}$ for further investigation.

\section{In vitro evaluation of antagonistic activities of the bacterial strains against root-lesion nematodes}

Bacterial suspensions were prepared in sterilized distilled water adding $1 \mathrm{ml}$ from each suspension to $100 \mathrm{ml}$ nutrient broth or King's $\mathrm{B}$ broth, later allowed to grow under shaking for $48 \mathrm{~h}$ at $25^{\circ} \mathrm{C}$. The cultures were centrifuged at $5000 \mathrm{rpm}$ for $15 \mathrm{~min}$ and the supernatants were evaluated for anti-nematicidal activities of tested bacteria against $P$. loosi. To perform the test, a total of $30 P$. loosi active juveniles were added into $1 \mathrm{ml}$ of each bacterial supernatant and incubated at $27-29^{\circ} \mathrm{C}$ for $48 \mathrm{~h}$. Sterilized distilled water was used as control. The experiment was conducted in a randomized completely design in three replicates and following formula was used to calculate percentage of nematode juvenile mortality, as normalized on controls.

$$
\text { Mortality }(\%)=\frac{[C 1-C 2]}{C 1} \times 100
$$

Where, $\mathrm{C} 1$ is the number of live nematodes juveniles in control treatments and $\mathrm{C} 2$ is the number of live nematodes juvenile counted in other treatments [34].

\section{Phenotypic characteristics of the bacterial strains}

The most effective bacterial strains were selected and their phenotypic features were characterized based on the standard bacteriological methods [35]

\section{Protease test}

This test was carried out using skim milk agar (casein peptone $5 \mathrm{~g}$, yeast extract $5 \mathrm{~g}$, skim milk $1 \mathrm{~g}$, glucose $1 \mathrm{~g}$ and agar $10.5 \mathrm{~g}$ per liter). Bacterial strains were inoculated on casein agar medium and the plates were incubated at $27^{\circ} \mathrm{C}$ for 48 hours. The clear zones around the colonies were considered as positive reaction [36].

\section{Results}

\section{Isolation of antagonistic bacterial strains}

Antagonistic activities of the challenged bacterial strains were determined based on juvenile mortality. The strains nematicidal activities were quite variable ranking from 14.15 to $95.24 \%$. Among the 34 tested Pseudomonas strains, 4 strains of P. fluorescens (RH-36, RH-25, RH-79 and RH-37) showed high levels of antagonistic activity (Group A). Within this group, P. fluorescens biovar I (RH-36) ranked first causing $95.24 \%$ of juvenile mortality (Table 1 and 3). Strains RH-

\begin{tabular}{|l|l|l|l|l|l|}
\hline Strain & Mortality (\%) & $\begin{array}{l}\text { Statistical } \\
\text { group }\end{array}$ & Strain & Mortality (\%) & Significance \\
\hline Rh-36 & 95.24 & A & Rh-77 & 26.37 & FG \\
\hline Rh-25 & 84.98 & A & Rh-33 & 20.00 & FG \\
\hline Rh-79 & 91.90 & A & Rh-15 & 20.00 & FG \\
\hline Rh-96 & 70.15 & BC & Rh-74 & 22.94 & FG \\
\hline Rh-35 & 71.17 & BC & Rh-12 & 28.87 & FGH \\
\hline Rh-37 & 87.44 & A & Rh-11 & 22.28 & FG \\
\hline Rh-19 & 63.10 & C & Rh-76 & 22.17 & FG \\
\hline Rh-39 & 82.62 & AB & Rh-53 & 17.15 & G \\
\hline Rh-50 & 29.15 & EFG & Rh-43 & 27.85 & FG \\
\hline Rh-17 & 24.39 & FG & Rh-85 & 42.95 & DE \\
\hline Rh-60 & 26.04 & FG & Rh-99 & 23.68 & FG \\
\hline Rh-57 & 20.49 & FG & Rh-28 & 33.83 & DEF \\
\hline Rh-31 & 20.01 & FG & Rh-23 & 34.68 & DEF \\
\hline Rh-63 & 18.69 & FG & Rh-48 & 44.45 & D \\
\hline Rh-41 & 22.86 & FG & Rh-94 & 24.25 & FG \\
\hline Rh-78 & 21.43 & FG & Rh-44 & 34.24 & DEF \\
\hline Rh-16 & 25.47 & FG & Control & 15.63 & G \\
\hline & & & & & \\
\hline
\end{tabular}

Data are means of three replications

Values followed by the same letters in each column are not significantly different $(\alpha=0.05)$

Table 1: In vitro antagonistic activities of 34 rhizosphere bacteria of tea plants against Pratylenchus loosi based on juvenile mortality.

\begin{tabular}{|l|l|l|l|l|l|l|l|l|}
\hline $\mathrm{RH}-96$ & $\mathrm{RH}-19$ & $\mathrm{RH}-79$ & $\mathrm{RH}-39$ & $\mathrm{RH}-37$ & $\mathrm{RH}-36$ & $\mathrm{RH}-35$ & $\mathrm{RH}-25$ & Properties \\
\hline+ & + & + & + & + & + & + & - & Fluorescent pigment \\
\hline- & - & - & - & - & - & - & - & Oxidase \\
\hline- & - & - & - & - & - & - & + & Pectolytic activity \\
\hline+ & - & - & - & + & - & + & + & Nitrate to nitrite \\
\hline+ & + & + & - & + & + & + & + & Gelatin liquefaction \\
\hline+ & - & - & + & + & - & + & + & Growth at $41^{\circ} \mathrm{C}$ \\
\hline- & + & + & - & - & + & - & - & Growth at $4{ }^{\circ} \mathrm{C}$ \\
\hline+ & - & - & - & + & - & + & - & Growth at pH 5.7 \\
\hline- & + & + & - & - & + & - & - & Growth in $7 \%$ NaCl \\
\hline+ & + & + & + & + & + & + & + & Growth on: Glucose \\
\hline+ & + & + & - & + & + & + & - & D-galactose \\
\hline- & + & + & - & - & + & - & - & Saccharate \\
\hline+ & + & + & + & + & + & + & - & Xylose \\
\hline+ & + & + & + & + & + & + & - & Arabinose \\
\hline+ & + & + & - & + & + & + & - & Sorbitol \\
\hline+ & + & + & + & + & + & + & + & Mannitol \\
\hline- & - & - & + & - & - & - & - & Arginine \\
\hline+ & - & + & + & + & + & + & + & L-tryptophan \\
\hline
\end{tabular}

+: Positive Reaction; - : Negative Reaction

Table 2: Characteristics of eight antagonistic Pseudomonas strains against Pratylenchus loosi.

79, RH-25 and RH-37 showed 84.98, 91.90 and 87.44\% nematicidal activities, respectively.

\section{Phenotypic features determination of the bacterial strains}

Based on rates of nematicidal activities of the bacterial strains, 8 isolates were chosen for further characterization, based on Schaad et al. [35] (Table 2).

\section{Protease test}

Cassese is an exoenzyme which produces by some bacteria to degrade casein. All tested bacterial strains showing antagonistic activity against Pratylenchus loosi were able to produce proteases. Among the tested strains three species of $P$. fluorescent bv. IV (RH-37) and $P$. 


\begin{tabular}{|l|c|c|}
\hline Bacterial strain name & Mortality (\%) & Significance \\
\hline $\begin{array}{l}\text { Pseudomonas fluorescent bv. } \\
\text { I (Rh-36) }\end{array}$ & 95.24 & A \\
\hline P. aeroginosa (Rh-25) & 84.98 & A \\
\hline P. fluorescent bv. I (Rh-79) & 91.90 & A \\
\hline P. fluorescent bv. IV (Rh-96) & 70.15 & BC \\
\hline P. fluorescent bv. IV (Rh-35) & 71.17 & BC \\
\hline P. fluorescent bv. IV (Rh-37) & 87.44 & A \\
\hline P. fluorescent bv. I (Rh-19) & 63.10 & C \\
\hline P. fluorescent bv. V (Rh-39) & 82.62 & AB \\
\hline Control (distilled water) & 15.63 & G \\
\hline
\end{tabular}

Table 3: The degree of nematicidal activities of effective antagonistic bacteria based on $\%$ of juvenile mortality.

\begin{tabular}{|l|l|}
\hline Bacteria Strain & Average halo produced on medium containing casein $(\mathrm{mm})$ \\
\hline $\mathrm{RH}-35$ & 9.16 \\
\hline $\mathrm{RH}-37$ & 14.6 \\
\hline $\mathrm{RH}-79$ & 8.5 \\
\hline $\mathrm{RH}-39$ & 11.66 \\
\hline $\mathrm{RH}-36$ & 9.6 \\
\hline $\mathrm{RH}-19$ & 12.66 \\
\hline $\mathrm{RH}-25$ & 14.5 \\
\hline $\mathrm{RH}-96$ & 5.3 \\
\hline
\end{tabular}

Table 4: Tested strains three species of $P$. fluorescent bv. IV(RH-37) and $P$ aeruginosa $(\mathrm{RH}-25)$ showed the largest clear zones, indicating high level of protease production.

aeruginosa (RH-25) showed the largest clear zones, indicating high level of protease production (Table 4).

\section{Discussion}

Biological control of soil-borne pathogens by rhizosphere bacteria is notoriously susceptible to alterations in experimental conditions $[37,38]$. Among rhizosphere nematode antagonists, the Gram+ Pasteuria penetrans is an antagonist specialized against root knot nematodes [39-41]. Beside this bacterium, also nematode trapping fungi can reduce populations of nematodes [42]. According to Maafi [43] isolates of Pasteuria penetrans do not attach to second stage juveniles of $P$. loosi.

A protozoan endoparasite was occasionally registered from $P$. loosi, and its control impact was not confirmed [2]. For several years, compost and soil modifications have been practiced in a unified management program to suppress $P$. loosi in Sri Lanka. In addition to many other useful effects, these practices were known to enhance population densities of natural predators and parasites of parasitic nematodes $[5,44,45]$.

In this study, eight isolates belonging to the genus Pseudomonas were found to possess a pronounced nematicidal activity. Almost all selected isolates showed similarities in diagnostic properties with $P$. fluorescens, whereas only $\mathrm{Rh}-25$ - was identified as $P$. aeroginosa. Pseudomonas fluorescens and $P$. aeruginosa showed variable antagonistic activities against $P$. loosi, reducing its juvenile in range by $63.1-95.2 \%$.

These findings are new for Iran. In previous studies [46] soil application of $P$. fluorescence similarly reduced soil and root populations of lesion nematodes viz., Radopholus similis, P. coffee and Helicotylenchus multicinctus in comparison with carbofuron 3G. Fluorescent products by Pseudomonas were found to have inhibitory effect on hatching and penetration of nematodes and on pigeon pea roots colonization [47].
Based on statistical differences observed the isolates of $P$. fluorescence showed different effects, as these bacteria affected nematodes conferring them a different appearance and colors, ranging from brown, to black some specimens appearing also degenerated.

According to Westcott and Kluepfel [23], prior applications of $P$. fluorescens prevented egg hatchinh and affected juveniles due to exotoxin formation and disruption of normal cellular nematode metabolism. It is important to note that some of these bacteria induce plant systemic resistance for indirect control of soil pathogens, in addition to exhibited antibiosis [48].

Some bacterial species with nematicidal actuality have been applied for control of root-knot nematodes: among them Streptomyces spp., Serratia spp., Bacillus spp., Azotobacter chroococcum, Rhizobioum, Corynebacterium and Pseudomonas. Eapen reported that treating pepper seedlings with isolates of $P$. fluorescens reduced the detriment effects due to Meloidogyne incognita. Similarly, insemination of wheat plants with $P$. fluorescens terminated in considerable lower nematode populations [49].

It is significant to point that rhizosphere of antagonistic plants may represent beneficial sources of potential biological control agents for nematodes [23] as suggested by prevention effects of $P$. fluorescens on M. incognita. However, this biovar proceeded from radish rhizosphere host for Meloidigyne spp. [48].

The results herein showed may represent a fraction of the effects related to the complex relationships among different types of microorganisms in the rhizosphere. PGPR species alone or with Rhizobium enhanced plant growth both in M. javanica and inoculated plants. Inoculation with Rhizobium spp. caused an increase in plant growth than the effect caused by any species of PGPR in nematodeinoculated plants. Combined use of Rhizobium with other species of PGPR also decreased galling and nematode propagation than their single inoculation [50].

All the antagonist bacteria are able to produce protease enzyme. Protease production is an effective mechanism for controlling nematodes.

Extracellular enzymes, including subtilisin-like serine protease, chitinase and collagenase, corresponding to the main chemical constituents of nematode cuticle and eggshell, have been reported to be involved in the infection as virulence factors [51]. In the interaction between pathogen and hosts, much experimental evidence supported that serine protease can destroy the integrity of cuticle to help penetration of pathogen $[52,53]$ and initiate or trap nematophagous fungi [54].

These preliminary results provide a strong incentive for further experiments on the use of rhizosphere bacteria in the biocontrol of plant parasitic nematodes. If the potential of these strains is confirmed, they could be used in the future in greenhouse and field conditions, to develop alternative, low cost and environment friendly technologies.

\section{Acknowledgement}

The authors gratefully acknowledge Dr. A. Ciancio, CNR, IST. Protezione Piante-Sez. Di Bari, Italia for his kind editing, revising and other commentary on an early draft of this article.

\section{References}

1. FAO (2010) Current situation and medium-term outlook for tropical fruits. Sugar and Beverages Group, Raw Materials, Tropical and Horticultural Products 
Service, Commodities and Trade Division, Food and Agriculture Organization of the United Nations.

2. Luc M, Sikora RA, Bridge J (2005) Plant Parasitic Nematodes in Subtropical and Tropical Agriculture. Nematode Parasite of Tea. CABI.

3. Campos VP, Sivapalan P, Gnanapragasm NC (1990) Nematode Parasites of Coffee, Cocoa and Tea. Plant Parasitic Nematodes in Tropical and Subtropical Agriculture. CAB International, UK.

4. Gnanapragasam NC, Mohotti M, Sureshkumar B, Udamulla GP (1993) Effect of "JAWAN" a neem based natural pesticide in controlling nematode pests of tea. Sri Lanka Journal of Tea Science 62: 47-52.

5. Sivapalan P (1972) Nematode Pest of Tea. Academic Press, New York, USA

6. Pourjam E, Waeyenberge L, Moens M, Geraert E (1999) Morphological, morphometrical and molecular study of Pratylenchus coffeae and P. loosi (Nematoda: Pratylenchus). International Symposium on Crop Protection 64: 391-401.

7. Seraji A (2007) Biology and population dynamics of tea root lesion nematode Pratylenchus loosi, in Iran and the possibility its loss assessment on the host using epidemiological models. Tarbiat Modarres University, Tehran, Iran.

8. Seraji A, Pourjam E, Safaie N, Maafi ZT (2010) Effect of tea root lesion nematode, Pratylenchus loosi, on tea quality in Iran. Proceedings of the 4th International Conference on O-CHA (Tea) Culture and Science, Shizuoka, Japan.

9. Zhang Z, Yuen GY, Sarath G, Penheiter AR (2001) Chitinases from the Plan Disease Biocontrol Agent, Stenotrophomonas maltophilia C3. Phytopathology 91: 204-211

10. Vey A, Hoagland RE, Butt TM (2001) Fungi as Biocontrol Agents: Progress, Problems and Potential. CABI Publishing, Wallingford.

11. Leite LG, Alves SB, Batista Filho A, Roberts DW (2005) Simple, inexpensive media for mass production of three entomophthoralean fungi. Mycol Res 109: 326-334.

12. Quesada-Moraga E, Vey A (2004) Bassiacridin, a protein toxic for locusts secreted by the entomopathogenic fungus Beauveria bassiana. Mycol Res 108: 441-452.

13. Small CL, Bidochka MJ (2005) Up-regulation of Prl, a subtilisin-like protease, during conidiation in the insect pathogen Metarhizium anisopliae. Mycol Res 109: 307-313.

14. Vizcaíno JA, Sanz L, Basilio A, Vicente F, Gutiérrez S, et al. (2005) Screening of antimicrobial activities in Trichoderma isolates representing three trichoderma sections. Mycol Res 109: 1397-1406.

15. Steddom K, Menge JA (2001) Evaluation of Continuous Application Technology for Delivery of the Biocontrol Agent Pseudomonas putida 06909-rif/nal. Plant disease. 85: 387-392.

16. Atkins SD, Hidalgo-Diaz L, Clark IM, Morton CO, de Oca NM, et al. (2003) Approaches for monitoring the release of Pochonia chlamydosporia var catenulata, a biocontrol agent of root-knot nematodes. Mycol Res 107: 206212.

17. Atkins SD, Mauchline TH, Kerry BR, Hirsch PR (2004) Development of a transformation system for the nematophagous fungus Pochonia chlamydosporia. Mycol Res 108: 654-661.

18. Duncan LW (1991) Current options for nematode management. Annu Rev Phytopathol 29: 469-490.

19. Barker KR, Koenning SR (1998) Developing sustainable systems for nematode management. Annu Rev Phytopathol 36: 165-205.

20. Kimpinski J, Arsenault WJ, Sturz AV (2001) Differential effect of nematicide treatments on tuber yields in early- and late-maturing potato cultivars. Plant Pathol 50: 509-514.

21. Abuzar S, Haseeb A ( 2010) Plant growth and plant parasitic nematodes in response to soil amendments with plant growth promoting rhizobacteria and inorganic fertilizer in Pigeon Pea, Cajanus cajon L. World Applied Sciences Journal 8: 411-413.

22. Oostendorp M, Sikora RA (1986) Seed treatment with antagonistic rhizobacteria for the suppression of Heterodera schachtii early root infection of sugar beet. Rev Nematol 9: 304
23. Kloepper JW, Rodriguez-Kabana R, Mclnroy JA, Young RW (1992) Rhizosphere bacteria antagonistic to soybean cyst (Heterodera glycines) and root-knot (Meloidogyne incognita) nematodes: identification by fatty acid analysis and frequency of biocontrol activity. Plant Soil 139: 75-84.

24. Westcott SWI, Kluepfel DA (1993) Inhibition of Criconemella xenoplax egg hatch by Pseudomonas aureofaciens. Phytopathology 83: 1245-1249.

25. Pedersen JF, Rodriguez-Kábana R, Shelby RA (1988) Ryegrass cultivars and entophyte install fescue affect nematodes in grass and succeeding soybean Agron J 80: 811-814.

26. Becker JO, Zavaleta-Majia E, Colbert SF, Schroth MN, Weinhold AR, et al (1988) Effects of rhizobacteria on root-knot nematodes and gall formation. Phytopathology 78: 1466-1469.

27. Oostendorp M, Sikora R (1990) In vitro interrelationship between rhizosphere bacteria and Heterodera schachtii. Rev Nematol 13: 269-274.

28. Siddiqui ZA, Mahmoud I (1993) Biological control of Meloidogyne incognita race 3 and Macrophomina phaseolina by Paecilomyces lilacinus and Bacillus subtilis alone and in combination on chickpea. Fundam. Applied Nematol 16: 215-218.

29. Siddiqui ZA, Mahmoud I (1995a) Management of Meloidogyne incognita race 3 and Macrophomina phaseolina by fungus culture filtrates and Bacillus subtilis on chickpea. Fundam. Applied Nematol 18: 71-76.

30. Siddiqui ZA, Mahmood I (1995b) Role of plant symbionts in nematode management. A review. Bioresour Technol 54: 217-226.

31. Siddiqui ZA, Mahmood I (1997) Interaction of Meloidogyne javanica, Fusarium solani and plant symbionts on chickpea. Thai J Agric Sci 30: 379-388.

32. Jenkins WR (1964) A rapid centrifugal-flotation technique for separating nematodes from soil. Plant Disease Reporter 48: 692.

33. Coolen WA, D'herde CJ (1972) A Method for the Quantitive Extraction of Nematodes forms Plant Tissue. Min Agriculture Ghent, Belgium.

34. Li B, Xie GL, Soad A, Coosemans J (2005) Suppression of Meloidogyne javanica by antagonistic and plant growth-promoting rhizobacteria. J Zhejiang Univ Sci B 6: 496-501.

35. Schaad NW, Jones JB, Chum W (2001) Laboratory Guide for Identification of Plant Pathogenic Bacteria. (3rdedn), APS Press, USA.

36. Olajuyigbe FM, Ajele JO (2005) Production dynamics of extracellular protease from Bacillus species. African Journal of Biotechnology 4: 776-779.

37. Deacon JW (1991) Significance of ecology in the development of biocontro agents against soil-borne plant pathogens. Biocontrol Science and Technology 1: $5-20$

38. Weller DM (1988) Biological control of soil borne plant pathogens in the rhizosphere with bacteria. Annu Rev Phytopathol 26: 379-407.

39. Daudi AT, Channer AG, Ahmed R, Gowen SR (1990) Pasteuria penetrance as a biological agent of Meloidogyne incognita in the field in Malawi. Brighton Crop Protection conf. Pest and Disease, Farnham.

40. Liu L, Kloepper JW, Tuzun S (1995) Induction of systemic resistance in cucumber against Fusarium wilts by plant growth-promoting rhizobacteria. Phytopathology 85: 695-698.

41. Shanthi A, Raieswari S, Sivakumar CV, Mehta UK (1998) Soil application of Pseudomonas fluorescens for the control of root-knot nematode Meloidogyne incognita on grapevine (Vitis viniferaL.) Nematology: Challenges and opportunities in $21^{\text {st }}$ century. Proceeding of the Third International Symposium of Afro-Asian Society of Nematologyists, (TISAASN'98), Sugar-cane Breeding Institute (ICAR), Coimbatore, India.

42. Mohotti KM, Briscoe BR, Gowen SR, Bridge J (1998) Are entomopathogenic nematodes susceptible to infection by the plant parasitic nematode biocontrol organism, Pasteuria penetrans. Proceedings of the Third International Symposium of Afro-Asian Society of Nematologists, Coimbatore, India.

43. Maafi ZT, (2000) Study of Pasteuria penetrans group on some plant parasitic nematodes and their host ranges in the North of Iran. Iran. J Plant Pathol 36: e221-e231.

44. Visser $T$ (1959) Observation on the prevalence and control of parasitic eelworms in tea. Tea quarterly 30: 96-107.

45. Gnanapragasm NC (1989) Varietal response of pepper to infestation by the burrowing nematode, Radopholus similis. Sri Lanka J Tea Sci 58: 5-8. 
Citation: Rahanandeh H, Khodakaramian G, Hassanzadeh N, Seraji A, Asghari SM (2012) Characteristics and Antagonistic Potential of Pseudomonas spp. against Pratylenchus loosi. J Plant Pathol Microb 3:140. doi:10.4172/2157-7471.1000140

46. Shanthi A, Rajendran G, Sivakumar M (2003) Biomanagement of lesion nematodes in banana. Proceedings of the 6th International PGPR Workshop, Calcutta, India.

47. Siddiqui S, Siddiqui ZA, Iqbal A (2005) Evaluation of fluorescent Pseudomonads and Bacillus isolates for the biocontrol of a wilt disease complex of pigeonpea. World J Microbiol Biotechnol 21: 729-732.

48. Ashoub AH, Amara MT (2010) Biocontrol Activity of Some Bacterial Genera Against Root-Knot nematode, Meloidogyne incognita. Journal of American Science 6: 321-328.

49. Mohamed ZK, El-Sayed SA, Radwan TEE, Abd El-Wahab GS (2009) Potency evaluation of Serratia marcescens and Pseudomonas fluorescens as biocontrol agents for root-knot nematodes in Egypt. J Applied Sci Res 4: 93-102.

50. Siddiqui ZA, Baghel G, Akhtar MS (2007) Biocontrol of Meloidogyne javanica by Rhizobium and plant growth-promoting rhizobacteria on lentil. World $\mathrm{J}$ Microbiol Biotechnol 23: 435-441.

51. Huang X, Zhao N, Zhang K (2004) Extracellular enzymes serving as virulence factors in nematophagous fungi involved in infection of the host. Res Microbio 155: 811-816.

52. Decraemer W, Karanastasi E, Brown D, Backeljau T (2003) Review of the ultrastructure of the nematode body cuticle and its phylogenetic interpretation. Biol Rev Camb Philos Soc 78: 465-510.

53. Qiuhong N, Xiaowei H, Baoyu T, Jinkui Y, Jiang L, et al. (2006) Bacillus sp. B16 kills nematodes with a serine protease identified as a pathogenic factor. App Microbiol Biotechnol 69: 722-730.

54. Ahman J, Johansson T, Olsson M, Punt PJ, van den Hondel CA, et al. (2002) Improving the pathogenicity of a nematode-trapping fungus by genetic engineering of a subtilisin with nematotoxic activity. Appl Environ Microbiol 68 3408-3415. 